\title{
Mineralogical changes caused by grape production in a regosol from subtropical Brazilian climate
}

\author{
Edson Campanhola Bortoluzzi • \\ Diovane Freire Moterle • \\ Danilo dos Santos Rheinheimer • \\ Carlos Alberto Casali • George W. Melo • \\ Gustavo Brunetto
}

Received: 19 January 2011 / Accepted: 16 March 2012 /Published online: 12 April 2012

(C) Springer-Verlag 2012

\begin{abstract}
Purpose Inadequate soil use and management practices promote commonly negative impacts on the soil constituents and their properties, with consequences to ecosystems. As the soil mineralogy can be permanently altered due to soil use, this approach can be used as a tool to monitor the anthropogenic pressure. The objective of the present study was to assess the mineralogical alterations of a Brazilian regosol used for grape production for 40 years in comparison with a soil under natural vegetation (forest), aiming to discuss anthropogenic pressure on soils.

Material and methods Soil samples were collected at depths of $0-0.20$ and $0.20-0.40 \mathrm{~m}$ from vineyard production and
\end{abstract}

Responsible editor: Stefan Norra

E. C. Bortoluzzi $(\bowtie)$

Faculty of Agronomy and Veterinary Medicine,

University of Passo Fundo,

99001-970, Passo Fundo, Rio Grande do Sul, Brazil

e-mail: edsonb@upf.br

D. F. Moterle

Federal Institute of Education,

Science and Technology of Rio Grande do Sul,

95700-000, Bento Gonçalves, Rio Grande do Sul, Brazil

D. dos Santos Rheinheimer - C. A. Casali

Federal University of Santa Maria,

97105-900, Santa Maria, Rio Grande do Sul, Brazil

G. W. Melo

Embrapa,

95700-000, Bento Gonçalves, Rio Grande do Sul, Brazil

G. Brunetto

Federal University of Santa Catarina,

88034-000, Florianópolis, Santa Catarina, Brazil natural vegetation sites. Physical and chemical parameters were analysed by classic approaches. Mineralogical analyses were carried out on $<2 \mathrm{~mm}$, silt and clay fractions. Clay minerals were estimated by the relative percentage of peak surface area of the X-ray patterns.

Results and discussion Grape production reduced the organic matter content by $28 \%$ and the clay content by $23 \%$ resulting in a decreasing cation exchange capacity. A similar clay fraction was observed in both soils, containing kaolinite, illite/mica and vermiculite with hydroxy-Al polymers interlayered. Neither gibbsite nor chlorite was found. However, in the soil under native vegetation, the proportion of illite (79\%) was higher than vermiculite (21\%). Whereas, in the soil used for grape production during 40 years, the formation of vermiculite was promoted.

Conclusions Grape production alters the proportions of soil constituents of the regosol, reducing clay fraction and organic matter contents, as well as promoting changes in the soil clay minerals with the formation of vermiculite to the detriment of illite, which suggests weathering acceleration and susceptibility to anthropogenic pressure.

Recommendations and perspectives Ecosystems in tropical and subtropical climates can be more easily and permanently altered due to anthropogenic pressure, mainly as a consequence of a great magnitude of phenomena such as temperature amplitude and rainfall that occurs in these regions. This is more worrying when soils are located on steep grades with a high anthropogenic pressure, like regosols in Southern Brazil. Thus, this study suggests that changes in soil mineralogy can be used as an important tool to assess anthropogenic pressure in ecosystems and that soil quality maintenance should be a priority in sensible landscapes to maintain the ecosystem quality. 
Keywords Anthropogenic pressure · Illite-vermiculite . Potassium · Soil quality · Vitis sp.

\section{Introduction}

Ecosystems in tropical and subtropical climates can be more easily and permanently altered due to anthropogenic pressure, mainly as a consequence of a great magnitude of phenomena such as temperature amplitude and rainfall that occurs in these regions (Pellegrini et al. 2010). This is more dangerous when soils are located on steep grades with a high anthropic pressure, like the Gaucho Highlands (Serra Gaúcha) in the state of Rio Grande do Sul, Brazil. This region is the most important and traditional grape- and wine-producing region of Brazil. The grape production frequently occurs in sloped to mountainous areas under a subtropical climate regime and over soils weakly developed from basic and intermediate igneous rocks. The cultivated soils are frequently regosols and chernozems, as classified by the World Reference Base for Soil Resources (FAO 2006), or neossolo and chernossolo, according the Brazilian Soil Classification System (Embrapa 2006). Although these are weakly developed soils, to achieve satisfactory grape production, it is necessary first to cut down the native forest, to correct soil acidity, as well as to apply nitrogen, potassium and phosphate fertilisers. Moreover, it is a common practice to apply a pesticide with copper sulphate. High anthropogenic pressure on the soil suggests great changes in chemical and physical properties. It is expected that organic and mineral constituents were also affected in proportions or in their natures.

In particular, $\mathrm{K}$ is the nutrient transported in greatest quantity annually through grape bunches (Brunetto et al. 2006). The soil $\mathrm{K}$ extraction process is thought to be responsible for mineralogical variation, especially in the silt and clay fraction of many soils (Hinsinger et al. 1992; Hinsinger and Jaillard 1993; Pal et al. 2001; Velde and Peck 2002; Pernes-Debuyser et al. 2003; Bortoluzzi et al. 2005; Barré et al. 2007, 2008a, b). K adsorbed on the functional groups of clay minerals and organic matter with weak bonding energy is easily available to plants (Barrow 1983; Barré et al. 2008a, b). Exhaustion of $\mathrm{K}^{+}$ in the soil solution, due to uptake, triggers the desorption of $\mathrm{K}$ adsorbed to particles of colloidal size, including $\mathrm{K}$ retained by the permanent negative charges of 2:1 clay minerals, which is considered to be non-exchangeable (Britzke et al. 2012). This process naturally occurs when there is a division of the particles and the hydration of the mica interlayers (Fanning et al. 1989). The lack of replacement of $\mathrm{K}$ exported through crops can accelerate the transformation of rigid interlayers into expansive interlayers due to the replacement of $\mathrm{K}^{+}$by other hydrated cations, such as $\mathrm{Ca}^{2+}$ and $\mathrm{Mg}^{2+}$ (Hinsinger and Jaillard 1993). Moreover, in the acidic soils of Southern Brazil, which have a high exchangeable aluminium content, neoformation of clay minerals with interlayered $\mathrm{Al}$ is favoured (Bortoluzzi et al. 2008).

In this context, mineralogical alterations are expected in little-weathered soils, which are submitted to frequent fertilisation and long periods of cultivation with permanent crops that absorb nutrients throughout the year. As the soil mineralogy can be permanently altered due to soil use, this approach can be used as a tool to evaluate anthropogenic pressure. Thus, the objective of the present study was to assess the alterations in soil constituents and mineralogy of a Brazilian regosol that has been used for grape production in the last 40 years, by comparison with a reference soil under native vegetation.

\section{Material and methods}

\subsection{Site description and sample collection}

This study was carried out in an area belonging to Embrapa Uva e Vinho (Embrapa Grapes and Wine; latitude, 29 $09^{\prime} \mathrm{S}$, and longitude, $51^{\circ} 31^{\prime} \mathrm{W}$ ) in Bento Gonçalves, in the state of Rio Grande do Sul, Southern Brazil (Fig. 1). The natural vegetation is classified as mixed ombrophilous forest of the Atlantic coast forest formation. The climate is humid subtropical, with rainfall around $1,800 \mathrm{~mm}$ per year and a mean annual temperature of $17.2{ }^{\circ} \mathrm{C}$. The geology comprises a Brazilian Serra Geral formation, with a lithology composed of basalt, rhyolites and rhyodacites formed in the Mesozoic era. A large fraction of the area is occupied with grape production although there are still some areas with natural vegetation.

In April 2006, samples in triplicate (with approximately $1 \mathrm{~kg}$ each) from a regosol, as classified by the World Reference Base for Soil Resources, or Neossolo Litólico, according the Brazilian Soil Classification System (Embrapa 2006), were collected from soil layers at depths of $0-0.20$ and 0.20-0.40 m. Samples were collected from soils under two conditions of use: (1) under grape production for 40 years, located in the upper part of topographic relief, with a $10 \%$ slope (vineyard regosol, VR), and (2) under mature natural vegetation (for more than 100 years) located in the same position of topographic relief (regosol under natural vegetation, RNV), which was used as a reference (Table 1, see Fig. 1). The vineyard, which produces the non-grafted Isabel cultivar, was planted in 1966 at a density of 1,525 plants per hectare $(3.5 \times 2.0 \mathrm{~m})$ and grown in a trellis system. The grape vines are fertilised annually with approximately $25 \mathrm{~kg} \mathrm{ha}^{-1}$ of $\mathrm{N}, 40 \mathrm{~kg} \mathrm{ha}^{-1}$ of $\mathrm{P}_{2} \mathrm{O}_{5}$ and $40 \mathrm{~kg} \mathrm{ha}^{-1}$ of $\mathrm{K}_{2} \mathrm{O}$. 
Fig. 1 Site location

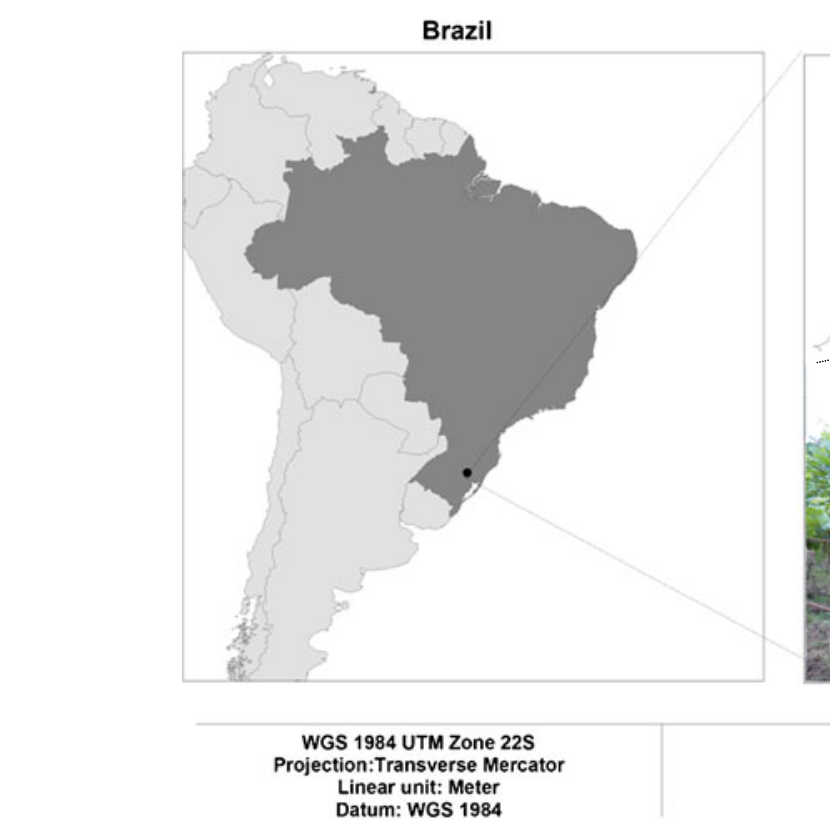

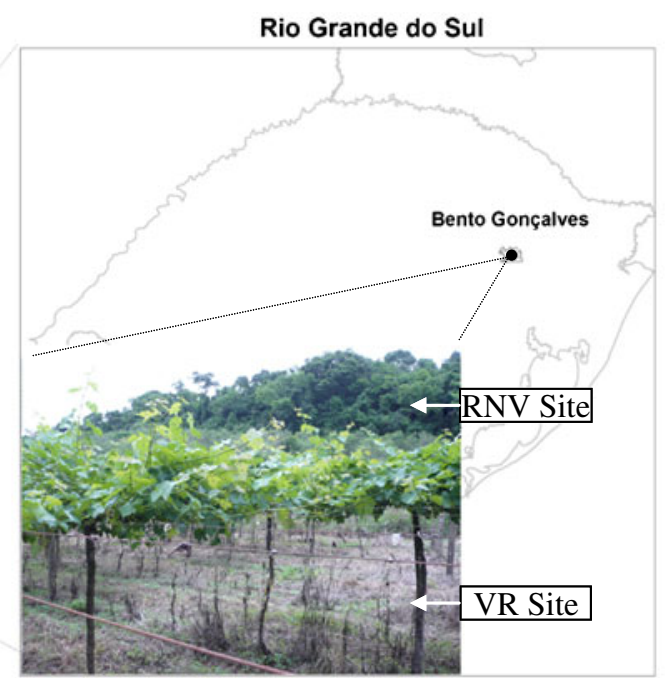

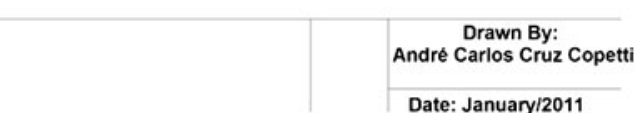

\subsection{Sample preparation and analysis procedures}

Soil samples were dried in air and passed through a sieve with a 2-mm screen. In addition, an aliquot was passed through a sieve with a $1-\mathrm{mm}$ screen to eliminate $\mathrm{Mn}-\mathrm{Fe}$ concretions and reserved for chemical analyses (Tedesco et al. 1995). The $\mathrm{pH}$ in $\mathrm{H}_{2} \mathrm{O}$ was measured with a $\mathrm{pH}$ meter. Exchangeable $\mathrm{Ca}^{2+}, \mathrm{Mg}^{2+}$ and $\mathrm{Al}^{3+}$ were displaced with $1 \mathrm{~mol} \mathrm{~L}{ }^{-1} \mathrm{KCl}$ solution. $\mathrm{Al}^{3+}$ was measured by titration with $0.0125 \mathrm{~mol} \mathrm{~L}^{-1} \mathrm{NaOH}$ solution while $\mathrm{Ca}^{2+}$ and $\mathrm{Mg}^{2+}$ were measured by flame atomic absorption spectrometry (FAAS) (Tedesco et al. 1995). Exchangeable $\mathrm{K}^{+}$and P were displaced with an acidic solution Mehlich-1 $\left(0.05 \mathrm{~mol} \mathrm{~L}^{-1}\right.$ $\mathrm{HCl}+0.0125 \mathrm{~mol} \mathrm{~L}^{-1} \mathrm{H}_{2} \mathrm{SO}_{4}$ ) and measured in flame atomic emission spectrometry and spectroscopy. Organic matter content was measured by humid combustion technique (Tedesco et al. 1995). The total potassium content (HF extractor) was measured in accordance with Pratt (1965). Iron contents extracted by dithionite/citrate/bicarbonate $\left(\mathrm{Fe}_{\mathrm{d}}\right)($ Mehra and Jackson 1960) and by ammonium oxalate $\left(\mathrm{Fe}_{\mathrm{o}}\right)$ were measured by FAAS, indicating the total and poorly crystalline fractions of iron oxides, respectively. The $\mathrm{Fe}_{\mathrm{o}} / \mathrm{Fe}_{\mathrm{d}}$ ratio was calculated, where values close to 1 indicate a low degree of weathering of the soils (Pédro 1979; Schwertmann et al. 1982). The effective cation exchange capacity (CEC) and CEC at pH 7.0 were calculated. All of these data are summarised in Table 1.

Soil mineralogical characterisation was carried out only for the soil from the 0 - to $0.20-\mathrm{m}$ layer, following the methodology described by Brindley and Brown (1980). The X-ray diffraction patterns were determined on powdered fine-earth samples using a Shimadzu XD-7A diffractometer $(\mathrm{Cu}-\mathrm{K} \alpha, 40 \mathrm{kV}$ and $20 \mathrm{~mA})$. Prior to diffractometry, samples were pre-treated by first destroying soil organic matter using $\mathrm{H}_{2} \mathrm{O}_{2}(30 \% v / v)$. Next, $25 \mathrm{~mL}$ of $\mathrm{NaOH}$ $\left(1.5 \mathrm{~mol} \mathrm{~L}^{-1}\right)$ was added to $450 \mathrm{~mL}$ of sample suspension to chemically and mechanically disperse the samples. Samples were then agitated for $24 \mathrm{~h}$ in a horizontal agitator. After this process, according to the Soil Survey Laboratory Information Manual (Soil Survey Staff 1995), the sand fraction $(>53 \mu \mathrm{m})$ was extracted with the aid of a sieve with a $53-\mu \mathrm{m}$ screen, and the clay fractions $(<2 \mu \mathrm{m})$ and silt fractions $(2-53 \mu \mathrm{m})$ were separated by sedimentation using the pipette method.

The X-ray patterns of the soil $(<2 \mathrm{~mm})$ and silt fractions were determined on randomly oriented powders from $2^{\circ}$ to $75^{\circ}$ 2theta, with $0.05^{\circ}$ 2theta steps and a counting time of $0.4 \mathrm{~s}$ per step. This configuration allowed us to identify the primary minerals in the soil samples.

Samples of the clay fraction were divided into two aliquots. The first was saturated with a $1-\mathrm{mol} \mathrm{L}^{-1}$ solution of $\mathrm{MgCl}_{2}$, and the second was saturated with a $1-\mathrm{mol} \mathrm{L}{ }^{-1}$ solution of $\mathrm{KCl}$. This saturation was performed three times, each time followed by mechanical agitation and removal of the supernatant. After saturation, excess ions were removed by following the same procedure, but with distilled water.

Approximately $2 \mathrm{~mL}$ of each saturated clay suspension was dropped onto the centre of a glass slide, which was then air-dried. These slides were used for the X-ray diffractometry after the following treatments: (a) Samples saturated with $\mathrm{Mg}$ were dried at room temperature under normal conditions and then submitted to solvation with ethylene glycol for 5 days; and (b) samples saturated with $\mathrm{K}$ were dried at room temperature under normal conditions and then submitted to thermal treatment at temperatures of 100, 300 and $550{ }^{\circ} \mathrm{C}$. The angular amplitude of the X-ray diffraction patterns was from 2 to $35^{\circ} 2$ theta. 
Table 1 Physical and chemical attributes of a vineyard regosol (VR) and a regosol under natural vegetation (RNV), collected in soil layers from 0 to 0.20 and $0.20-0.40 \mathrm{~m}$ in a subtropical Brazilian climate

\begin{tabular}{|c|c|c|c|c|}
\hline & \multicolumn{4}{|c|}{ Soil use } \\
\hline & \multicolumn{2}{|c|}{$\begin{array}{l}\text { Vineyard regosol } \\
\text { (VR) }\end{array}$} & \multicolumn{2}{|c|}{$\begin{array}{l}\text { Regosol under } \\
\text { natural } \\
\text { vegetation (RNV) }\end{array}$} \\
\hline Layer, m & $0-0.20$ & $0.20-0.40$ & $0-0.20$ & $0.20-0.40$ \\
\hline \multicolumn{5}{|l|}{ Soil constituents, $\mathrm{g} \mathrm{kg}^{-1}$} \\
\hline Clay $^{\mathrm{a}},<2 \mu \mathrm{m}$ & 221 & 250 & 286 & 294 \\
\hline Silt, $2-53 \mu \mathrm{m}$ & 430 & 477 & 430 & 440 \\
\hline Sand, $>53 \mu \mathrm{m}$ & 349 & 273 & 284 & 266 \\
\hline Silt/clay ratio & 1.95 & 1.91 & 1.50 & 1.50 \\
\hline $\begin{array}{l}\text { Organic matter, } \\
\mathrm{g} \mathrm{kg}^{-1}\end{array}$ & 43 & 17 & 60 & 20 \\
\hline $\mathrm{pH}$ in $\mathrm{H}_{2} \mathrm{O}$ & 6.2 & 6.1 & 4.7 & 4.6 \\
\hline $\mathrm{H}+\mathrm{Al}, \mathrm{cmol}_{\mathrm{c}} \mathrm{kg}^{-1 \mathrm{~b}}$ & 2.3 & 2.0 & 12.3 & 15.4 \\
\hline \multicolumn{5}{|l|}{ Exchangeable ions ${ }^{c}$} \\
\hline $\mathrm{Ca}, \mathrm{cmol}_{\mathrm{c}} \mathrm{kg}^{-1}$ & 8.0 & 5.1 & 4.0 & 1.1 \\
\hline $\mathrm{Mg}, \mathrm{cmol}_{\mathrm{c}} \mathrm{kg}^{-1}$ & 3.0 & 2.1 & 0.6 & 0.2 \\
\hline $\mathrm{Al}, \mathrm{cmol}_{\mathrm{c}} \mathrm{kg}^{-1}$ & 0.0 & 0.0 & 0.5 & 1.7 \\
\hline $\mathrm{K}, \mathrm{mg} \mathrm{kg}^{-1}$ & 138 & 80 & 168 & 121 \\
\hline $\mathrm{P}, \mathrm{mg} \mathrm{kg}^{-1}$ & 104 & 13 & 6.6 & 5.3 \\
\hline \multicolumn{5}{|c|}{ Cation exchange capacity-CEC ${ }^{\mathrm{d}}$} \\
\hline Effective CEC, $\mathrm{cmol}_{\mathrm{c}} \mathrm{kg}^{-1}$ & 11.3 & 7.4 & 5.5 & 3.3 \\
\hline $\mathrm{CEC}$ at $\mathrm{pH} 7.0, \mathrm{cmol}_{\mathrm{c}} \mathrm{kg}^{-1}$ & 13.7 & 9.4 & 17.8 & 18.7 \\
\hline Total $\mathrm{K}, \mathrm{mg} \mathrm{kg}^{-1 \mathrm{e}}$ & 6,590 & 5,590 & 6,580 & 5,640 \\
\hline $\mathrm{Fe}_{\mathrm{d}}, \mathrm{mg} \mathrm{kg}^{-1 \mathrm{f}}$ & 243 & 290 & 359 & 391 \\
\hline $\mathrm{Fe}_{\mathrm{o}}, \mathrm{mg} \mathrm{kg}^{-1}$ & 151 & 172 & 167 & 177 \\
\hline $\mathrm{Fe}_{\mathrm{o}} / \mathrm{Fe}_{\mathrm{d}}$ & 0.6 & 0.6 & 0.5 & 0.5 \\
\hline
\end{tabular}

${ }^{a}$ Clay fraction was performed using the pipette method; organic matter was measured by the wet combustion method (Embrapa 1997)

${ }^{\mathrm{b}} \mathrm{H}+\mathrm{Al}$ was determined by buffer solution (Tedesco et al. 1995)

${ }^{\mathrm{c}}$ Ion exchange was determined by Mehlich-1 (Tedesco et al. 1995)

${ }^{\mathrm{d}}$ Effective $\mathrm{CEC}$ is the sum of $\mathrm{K}, \mathrm{Ca}, \mathrm{Mg}$ and $\mathrm{Al}$, and $\mathrm{CEC}$ at $\mathrm{pH} 7.0$ is the sum of $\mathrm{K}, \mathrm{Ca}, \mathrm{Mg}$ and $\mathrm{H}+\mathrm{Al}$

e Total K was determined according to Pratt (1965)

${ }^{\mathrm{f}} \mathrm{Fe}_{\mathrm{d}}$ was extracted by dithionite-citrate-bicarbonate following Mehra and Jackson (1960); $\mathrm{Fe}_{\mathrm{o}}$ was extracted by ammonium oxalate following Embrapa (1997)

To discriminate between meta-halloysite and illite, $\mathrm{X}$-ray patterns were obtained at angles of $8-13^{\circ}$ of 2 theta of an aliquot of the clay fraction, prepared on a glass slide in dried and wet conditions. If a peak appears at $d=1.00 \mathrm{~nm}$ under high-moisture conditions and disappears after drying, it means the clay mineral easily loses water, confirming the presence of halloysite (Brindley and Brown 1980).

X-ray diffraction patterns from clay samples saturated with $\mathrm{Ca}$ and dried at room temperature were submitted to
EVA $^{\circledR}$ software for mathematical modelling of their peaks. For this purpose, the baseline of the X-ray diffraction patterns was extracted, generating a text file. The peaks found in the clay samples corresponding to section 001 were also mathematically modelled to identify mineral specimens using curves adjusted by the Origin ${ }^{\circledR}$ program v 5.0. A semiquantitative phase analysis was performed to determine the relative surface peak areas ( $S$ value) of the clay minerals (Hughes et al. 1994). Thus, the position and the surface of the modelled peaks (peak intensity and full width at half maximum) were compared as a way of estimating the relative participation of each mineral species (Hughes et al. 1994; Lanson 1997; Britzke et al. 2012).

The results were presented and discussed so as to show the effect of grape production on general soil characteristics and soil mineralogy in the different soil fractions, as compared with soil under native vegetation. Thus, for the mineralogical discrimination, the position and the surface area of the peaks in different situations were recorded, according to Lanson (1997).

\section{Results}

\subsection{Effect of grape production on soil attributes}

Clay values in the grape production (VR) and native vegetation (RNV) were 221 and $286 \mathrm{~g} \mathrm{~kg}^{-1}$, respectively, for the 0 - to 0.20 -m layer, and 250 and $294 \mathrm{~g} \mathrm{~kg}^{-1}$ for the 0.20 - to $0.40-\mathrm{m}$ layer (see Table 1). Both soils showed high silt content $\left(\sim 400 \mathrm{~g} \mathrm{~kg}^{-1}\right)$. Particles sized more than $2 \mathrm{~mm}$ were not found.

The organic matter content was greater under RNV $(60$ and $20 \mathrm{~g} \mathrm{~kg}^{-1}$ for the 0 - to $0.20-\mathrm{m}$ and $0.20-$ to $0.40-\mathrm{m}$ layers, respectively) than under VR (43 and $17 \mathrm{~g} \mathrm{~kg}^{-1}$ for the same layers). In the $\mathrm{VR} \mathrm{pH}$ in water, exchangeable calcium and magnesium content were higher than in the RNV. The phosphorus values were higher in the VR layers than in the RNV layers (see Table 1), due to the P fertilizations through the years, as well as the liming that increases the $\mathrm{P}$ availability in soils.

The potential acidity values $(\mathrm{H}+\mathrm{Al})$ were lower in the VR layers than in the RNV layers (see Table 1), due to the liming, in which lime is applied to the soil before planting, when it is needed, based on soil analysis. By consequence, the two RNV layers sampled presented an effective cation exchange capacity of around 48 and $44 \%$ less than the VR. The cation exchange capacity (CEC) at $\mathrm{pH} 7$ of two RNV layers sampled presented higher values (17.8 and $18.7 \mathrm{cmol}_{\mathrm{c}} \mathrm{kg}^{-1}$ ) associated to the higher values of potential acidity $(\mathrm{H}+\mathrm{Al})$. These findings likely are due to the addition of acidity correctives to the VR, while the natural acidity of organic matter in the soil was maintained under native vegetation. 
3.2 Mineralogical characterisation of the soil $(<2 \mathrm{~mm})$ and silt $(2-53 \mu \mathrm{m})$ fractions

The X-ray powder diffraction patterns obtained from soil and silt fractions showed that the VR and RNV had similar mineralogical constitutions (Fig. 2). In the X-ray diffraction patterns, peaks corresponding to quartz were found. An intense peak at $d=0.406 \mathrm{~nm}$, together with peaks at $d=0.249,0.282$ and $0.314 \mathrm{~nm}$ of little intensity, indicates the presence of cristobalite (see Fig. 2). This interpretation is in agreement with Brindley and Brown (1980).

Peaks attributed to $\mathrm{K}$ and Ca feldspar, such as $d=0.331$, 0.325 and $0.299 \mathrm{~nm}$ (Deer et al. 1965), are present in X-ray diffraction patterns, but they are masked by the quartz peaks (see Fig. 2.). Thus, the presence of both $\mathrm{K}$ and $\mathrm{Ca}$ feldspars is plausible, but in trace amounts. Peaks arising from the presence of copper-containing minerals were not found. Kaolinite and muscovite were found in the X-ray diffraction patterns (see Fig. 2). However, gibbsite was not found. The presence of muscovite is consistent with the total $\mathrm{K}$ content in soils (see Table 1). Hematite was identified in all soil fractions studied. This Fe-oxide is commonly found in soils in a subtropical climate (Schwertmann and Taylor 1989). The presence of goethite cannot be confirmed in the X-ray patterns. A peak at $d=0.254 \mathrm{~nm}$ may denote the presence of a ferrihydrite (Schwertmann and Taylor 1989). The presence of rutile and anatase is confirmed on X-ray diffraction patterns, despite their less intense peaks (see Fig. 2).
Fig. 2 X-ray powder diffraction patterns of the $<2 \mathrm{~mm}$ (a) and 2- to $53-\mu \mathrm{m}$

(b) fractions from the 0 - to $0.20-\mathrm{m}$ layer of a vineyard regosol $(V R)$ and a regosol under natural vegetation $(R N V)$, in a subtropical Brazilian climate. Ms muscovite, Kao kaolinite, $Q z$ quartz, $H m$ hematite, $\mathrm{F}$ feldspar, $\mathrm{Cr}$ cristobalite, $R$ rutile, $F h$ ferrihydrite

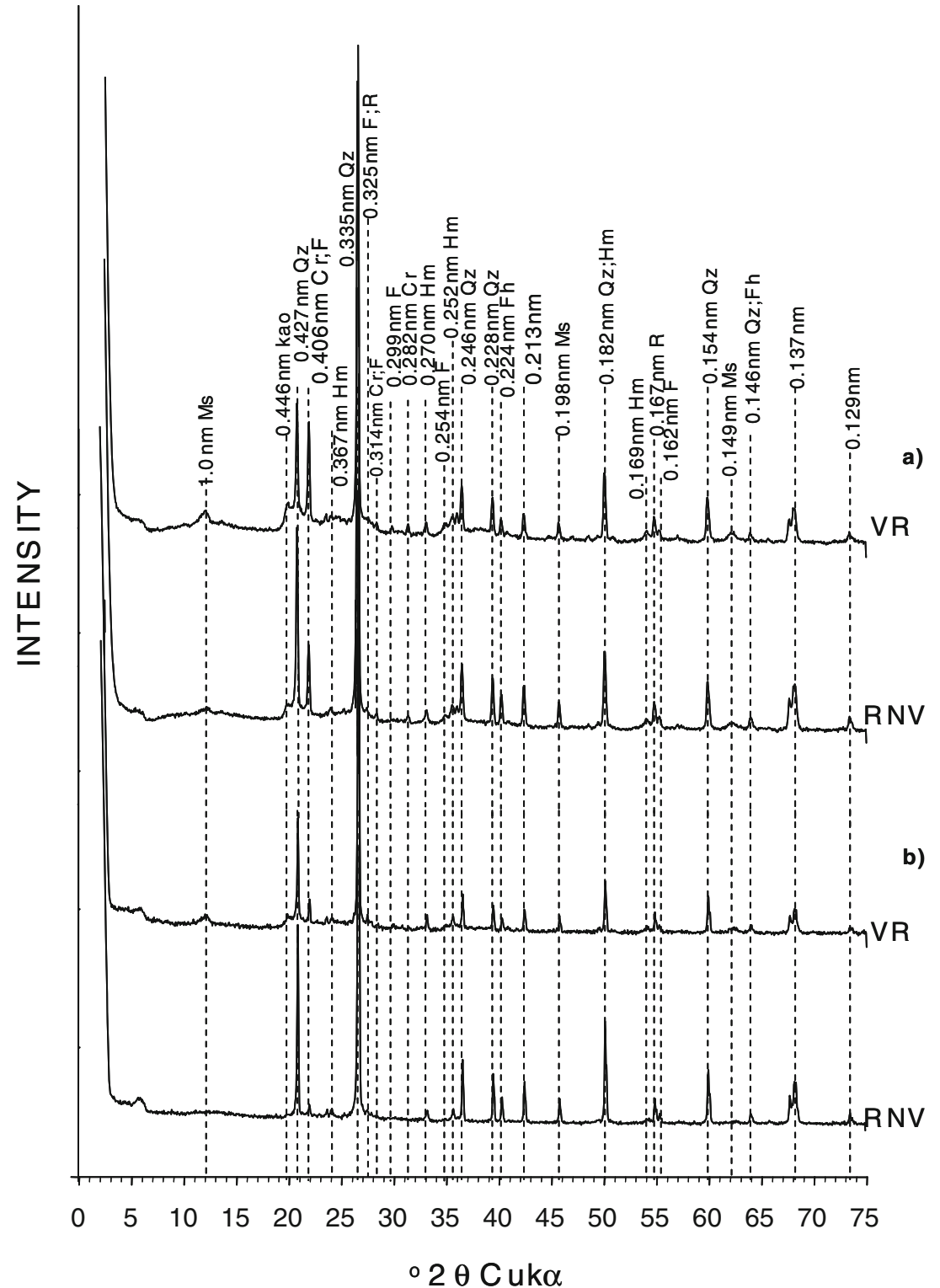


3.3 Mineralogical characterisation of clay fraction $(<2 \mu \mathrm{m})$

The X-ray diffraction patterns of the $<2 \mu \mathrm{m}$ fraction under normal conditions (Fig. 3a) showed the presence of one peak (001) with a basal distance of $d=0.720 \mathrm{~nm}$ and one peak (002) at $d=0.359 \mathrm{~nm}$, indicating that kaolinite is present in both soils. The potential presence of meta-halloysite was ruled out due to the invariability of the position of the $d=0.720 \mathrm{~nm}$ peak under hydrated and non-hydrated conditions (Brindley and Brown 1980). The presence of interstratified kaolinite-smectite was also refuted due to the invariability of the position of the peak at $d=0.720 \mathrm{~nm}$ under normal conditions and after saturation with ethylene glycol (see Fig. 3b) (Schultz et al. 1971). Confirmation of the disappearance of the peak at $d=0.720 \mathrm{~nm}$ after heating at $550{ }^{\circ} \mathrm{C}$ corroborates the presence of kaolinite (Fig. 4) (Moore and Reynolds 1997).

Illite is also found in X-ray diffraction patterns (see Fig. 3a). It can also be observed in cristobalite in clay fractions, as well as quartz; these minerals probably originated from rock. The presence of smectite $(d=1.51-1.52 \mathrm{~nm})$ was excluded because the large peak at $d=1.430 \mathrm{~nm}$ did not exhibit sensitivity to solvation with ethylene glycol (see Fig. 3b), and there was no closing of the interlayers in response to heating at $100{ }^{\circ} \mathrm{C}$ (see Fig. 4). The large band around $d=1.430 \mathrm{~nm}$ under X-ray diffraction patterns at room temperature was shifted to $d=1.00 \mathrm{~nm}$ after heating at $350{ }^{\circ} \mathrm{C}$, indicating complete closing of the interlayers of 2:1 clay minerals (see Fig. 4). Thus, the presence of vermiculite was confirmed (Inoue et al. 1989; Moore and Reynolds 1997). Therefore, a part of the vermiculite peak, after heating to $350^{\circ}$ C, produced a partial displacement at $d=1.0 \mathrm{~nm}$ (see Fig. 4) due to the bonds of hydroxy-Al polymers in the siloxane surface. In contrast, the collapse of the peak at $d=1.0 \mathrm{~nm}$ was completed at $550{ }^{\circ} \mathrm{C}$ (see Fig. 4), corroborating the absence of chlorite and the presence of vermiculite with the hydroxy-Al interlayer in partial positions (Kampf et al. 1995; Velde 2001; Bortoluzzi et al. 2008; Inda et al. 2010). Chlorite is confirmed when a very sharp peak at $1.4 \mathrm{~nm}$ is found after heating, even at $550{ }^{\circ} \mathrm{C}$ (Barnhisel and Bertsch 1989).

The intensity of the peak at $d=1.00 \mathrm{~nm}$ under normal conditions (saturated with $\mathrm{K}$ and $\mathrm{Ca}$ ) was lower in the VR than in the RNV soil (see Figs. 3 and 4). In addition, the $d=1.40 \mathrm{~nm}$ band was wider in the VR than in the RNV soil. The kaolinite peak was similar in position and intensity in both soils. Based on the principle that the size of the mineral particles and the degree of crystallinity are similar (Moore and Reynolds 1997; Hughes et al. 1994), the relative quantity of the clay minerals in the sample may explain the differences in the peaks on X-ray diffraction patterns. Modelling of the Xray diffraction patterns in their peaks (Fig. 5) shows that the illite peak was more intense in the RNV soil than the peak at $d=1.42 \mathrm{~nm}$, which was more intense in the VR soil. In the RNV sample, $79 \%$ of the total surface area of all peaks corresponded to the illite $(d=1.01 \mathrm{~nm})$, and $21 \%$ corresponded to the vermiculite clay mineral $(d=1.42 \mathrm{~nm})$; in contrast, in the VR sample, the illite peak $(d=0.99 \mathrm{~nm})$ represented $24 \%$ of the total surface area of all peaks, and vermiculite $(d=1.44 \mathrm{~nm})$ clay mineral represented $76 \%$.

\section{Discussion}

Regosols on a pedological point of view are soils with a weakly developed profile, with a shallow A horizon on unconsolidated material, in this case directly on the rock
Fig. 3 X-ray diffraction patterns from angles 2 to $35^{\circ} 2$ theta, corresponding to reflections of the $(00 l)$ plane, of the $<2-\mu \mathrm{m}$ fraction of soil from the 0 - to 0.20 -m layer saturated with $\mathrm{Mg}$ a under normal conditions and $\mathbf{b}$ solvated with ethylene glycol $(E G)$. VR is a vineyard regosol and RNV is a regosol under natural vegetation in a subtropical Brazilian climate
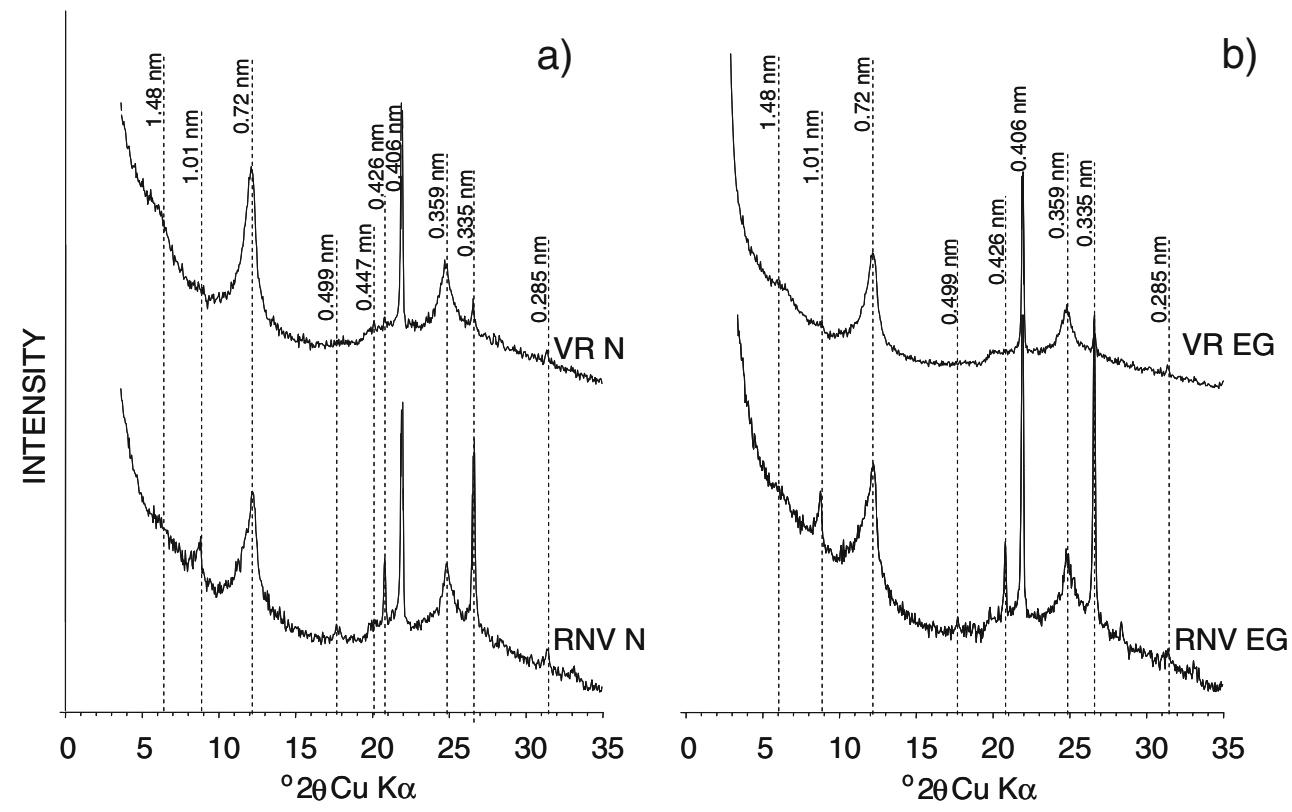


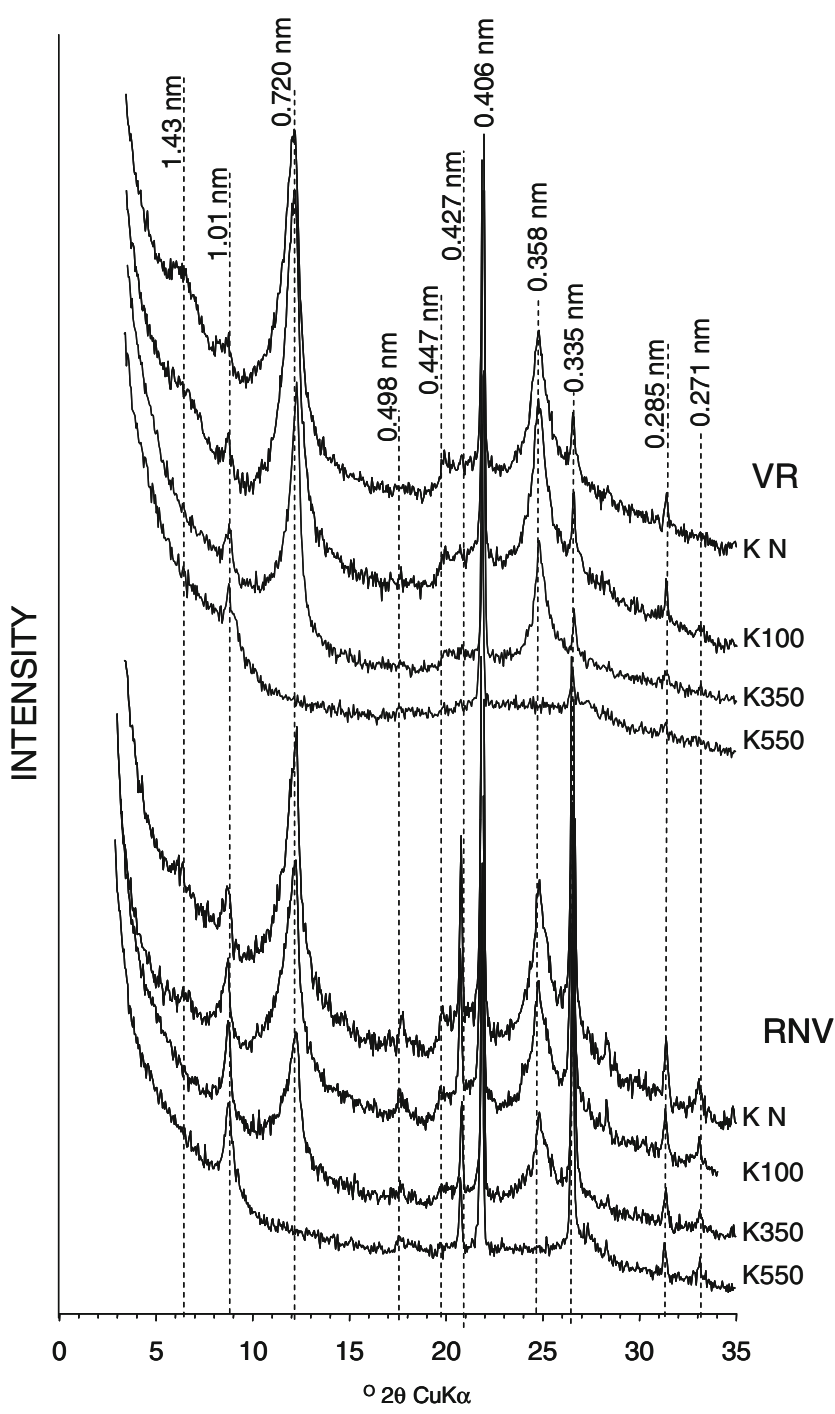

Fig. 4 X-ray diffraction patterns from angles 2 to $35^{\circ} 2$ theta of the $<2-\mu \mathrm{m}$ fraction of the soil from the 0 - to $0.20-\mathrm{m}$ layer saturated with $\mathrm{K}$ under normal conditions $(K N)$ and heated to $100{ }^{\circ} \mathrm{C}(K 100), 350{ }^{\circ} \mathrm{C}(K 350)$ and $550{ }^{\circ} \mathrm{C}(K 550)$. VR is a vineyard regosol and $\mathrm{RNV}$ is a regosol under natural vegetation in a subtropical Brazilian climate

and located in eroding lands on the top part of the relief of a mountainous terrain (FAO 2006). The regosol of this study presents high silt and organic matter contents, but their quantities were altered by soil use. Iron was found in both soils (see Table 1); almost half was in the crystallised form, suggesting an intensive weathering. The ferrihydrite oxide represents the largest part of $\mathrm{Fe}$ oxides, but hematite was also present. Ferrihydrite is an oxide intermediate in the formation of hematite, a mineral that occurs frequently in weathered soils of the region under study (Schwertmann et al. 1982).

Concerning the soil use, the amounts of $\mathrm{Fe}_{\mathrm{d}}$ ( $\mathrm{Fe}$ extracted by dithionite) were greater in the RNV than in the VR, by 47 and $34 \%$ for both layers studied, while $\mathrm{Fe}_{\mathrm{o}}$ ( $\mathrm{Fe}$ extracted by oxalate) presented a smaller variation between the treatments

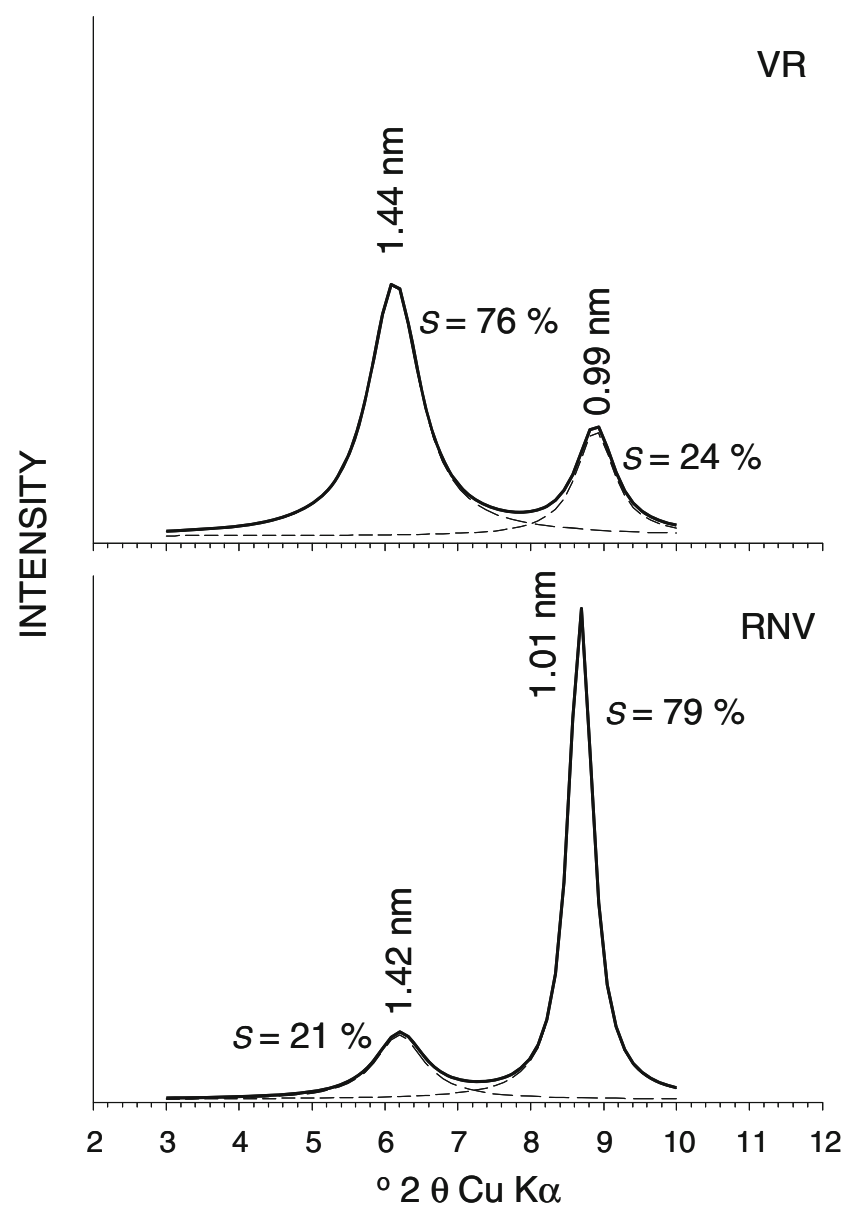

Fig. 5 X-ray diffraction patterns modelled from angles 3 to $10^{\circ} 2$ theta, corresponding to the $(O O l)$ reflections of the $<2-\mu \mathrm{m}$ fraction of soil from the 0 - to $0.20-\mathrm{m}$ layer saturated with $\mathrm{Ca}$ under normal conditions. $\mathrm{VR}$ is a vineyard regosol and RNV is a regosol under natural vegetation in a subtropical Brazilian climate; $S$ is the proportion of surface area. The solid line indicates experimental curve, and the dashed line indicates the best-fit curve

(see Table 1). The $\mathrm{Fe}_{\mathrm{o}} / \mathrm{Fe}_{\mathrm{d}}$ ratio was 0.6 in the VR soil and 0.5 in the RNV soil. The high $\mathrm{pH}$ values induced by lime application in VR may be affecting the iron forms in VR (Alekseeva et al. 2011).

The higher silt fraction, which makes up around $40 \%$ of regosols studied here, is associated with both the mediumand long-term supply of elements and is also an indicator of the weak textural evolution of this soil (Pal et al. 2001; Wilson 1999). Nevertheless, differences in the mineralogy of coarse fractions ( $2 \mathrm{~mm}$ and silt fractions) due to the soil uses were not observed. This is not only because the soils are exposed to similar weathering conditions, but also because the coarse fractions are less sensitive to modifications caused by soil use.

In this context, the great change was found on soil constituent contents. Grape production promoted changes in pedogenesis, diminishing clay and soil organic matter contents, respectively, due to a selective particle size erosion and higher 
organic decomposition process (Phillips 2007; Minasny et al. 2008). The texture was classified as clay loam for RNV and loam for VR. The lower clay contents found in VR for both depths indicate selective particle loss by the erosion process (Phillips 2007). The erosion process on highly sloped areas tends to carry the rich fine-sized clay particles (Pellegrini et al. 2010). The consequences are on the soil negative charges, reducing the soil CEC (Bortoluzzi et al. 2006) and exchangeable ions, like potassium (see Table 1). Moreover, the VR layers had larger values of $\mathrm{pH}$ in water, exchangeable calcium and magnesium content and available phosphorus due to fertilizer inputs (see Table 1). Despite the higher K sorption on clay minerals with increase of $\mathrm{pH}$ values (Inoue 1983), low exchangeable $\mathrm{K}$ values were verified in VR due to the loss of organic matter and clay contents.

Changes due to the soil use and management are more probable on fine grain sizes of soils. However, in soils under both uses, i.e. native forest and grape production, a similar mineralogical composition was found, suggesting that qualitatively, the mineralogy was not affected by grape production. In this sense, the presence of one or other clay minerals, such as kaolinite, vermiculite and illite, is probably due to the transformation of primary minerals. In addition, the presence of $\mathrm{Al}$ polymers partially within vermiculite collapses at $550{ }^{\circ} \mathrm{C}$ (Barnhisel and Bertsch 1989). This behaviour is due to the presence of high amounts of $\mathrm{Al}$ in the soil solution, conditions typically found in this region (Kampf et al. 1995; Bortoluzzi et al. 2008; Inda et al. 2010). Iron in any degree of crystallization can also be observed. As reported by Bhattacharyya et al. (2000) high charged 2:1 structure clay minerals can be found together with oxides.

A shift in soil use from a native forest to an agricultural system leads to major changes in electrochemical and physical properties of soil. In this study, it was possible to observe that although the $\mathrm{K}$ fertiliser has been applied for 40 years to the vineyard regosol, the total $\mathrm{K}$ content of this soil resulted in similar values to the reference one (native forest) (see Table 1). This amount of $\mathrm{K}$ is not enough to maintain the original illite proportion in the VR (see Fig. 2). Therefore, this soil has undergone an intense vermiculitization process, i.e. the proportion of vermiculite increased at expenses of the illite (see Fig. 5). Similar phenomena were observed in the literature, for example by Velde and Peck (2002) and Bortoluzzi et al. (2005) in a native field used for annual crops and deprived of potassium fertilisation under successive corn crops.

From an agronomic point of view, the conversion of land to agriculture can be positive, provided good soil management is carried out to reduce the risk of soil quality loss and its environmental consequences. However, the processes that remove $\mathrm{K}$ from interlayers also induce the formation of interlayered $\mathrm{Al}$ polymers, as previously observed in soils of the region under study (Kampf et al. 1995; Bortoluzzi et al. 2008; Inda et al. 2010). Nevertheless, the clay and organic matter losses in VR give rise to a CEC at $\mathrm{pH} 7$ diminishing as compared with the RNV, a process called regressive pedogenesis by Minasny et al. (2008). Geochemical conditions of the soil solution can be responsible for changes in soil mineralogy, particularly in the case of littlealtered soils, such as those studied in the present work (Blake et al. 1999; Pernes-Debuyser et al. 2003). In this light, a question arises about how long it will be possible to continue the agricultural cultivation practices as employed in the studied area without compromise to the quality of the soil ecosystem. Ecosystems in tropical and subtropical climates can be more easily and permanently altered due to anthropogenic pressure, mainly as a consequence of the great magnitude of phenomena such as temperature amplitude and rainfall that occurs in these regions. Thus, this study suggests that changes in soil mineralogy can be used as an important tool to assess the anthropogenic pressure in ecosystems and that soil quality maintenance should be a priority in sensible landscapes to maintain the ecosystem quality.

\section{Conclusions}

Forty years of grape production affected the constituents of the soil, by reducing the clay and organic matter content. A similar mineralogy was observed in the silt and sand fractions, which were composed of cristobalite, quartz and mica, as well as small quantities of feldspar and iron oxides. Neither gibbsite nor chlorite was found. As regards the clay fraction, it presents 2:1 clay minerals, as illite and vermiculite with an $\mathrm{Al}$ polymer interlayer.

Conclusively, grape production promotes alterations in soil clay mineralogy. Basically, there is a transformation of illite into vermiculite, induced by $\mathrm{K}$ lost from the interlayer despite $\mathrm{K}$ fertilization practices. Forty years of grape soil cultivation accelerated soil weathering and soil degradation, diminishing soil quality and ecosystem sustainability. Soil quality maintenance should be a priority in sensible landscape on a subtropical climate to maintain the ecosystem quality.

Acknowledgments The authors thank A.C. Copetti, V. Scanagatta, A. Mussnich, João T.D. Oliveira and Laboratory of Magnetism and Magnetic Materials (LMMM-UFSM) for assistance in this study. E.C. Bortoluzzi and D.S. Rheinheimer thank the CNPq for fellowships.

\section{References}

Alekseeva T, Alekseev A, Xu R-K, Zhao A-Z, Kalinin P (2011) Effect of soil acidification induced by a tea plantation on chemical and mineralogical properties of Alfisols in eastern China. Environ Geochem Health 33:137-148 
Barnhisel RI, Bertsch PM (1989) Chlorites and hydroxy interlayered vermiculite and smectite. In: Dixon JB, Weed SB (eds) Minerals in soil environments. 2nd edition, Soil Sci Soc Am, Madison, Wisconsin, USA, 729-788 pp. (SSSA series, no 1)

Barré P, Velde B, Catel N, Abbadie L (2007) Soil-plant potassium transfer: impact of plant activity on clay minerals as seen from Xray diffraction. Plant Soil 292:137-146

Barré P, Montagnier C, Chenu C, Abbadie L, Velde B (2008a) Clay minerals as a soil potassium reservoir: observation and quantification through X-ray diffraction. Plant Soil 302:213-220

Barré P, Velde B, Fontaine C, Catel N, Abbadie L (2008b) Which 2:1 clay minerals are involved in the soil potassium reservoir? Insights from potassium addition or removal experiments on three temperate grassland soil clay assemblages. Geoderma 146:216223

Barrow NJ (1983) A mechanistic model for describing the sorption and desorption of phosphate by soil. J Soil Sci 34:733-750

Bhattacharyya T, Pal DK, Srivastava P (2000) Formation of gibbsite in the presence of 2:1 minerals: an example from Ultisols of northeast India. Clay Miner 35:827-840

Blake L, Goulding KWT, Mott CJB, Johnston AE (1999) Changes in soil chemistry accompanying acidification over more than 100 years under woodland and grass at Rothamsted Experimental Station, UK. Eur J Soil Sci 50:401-412

Bortoluzzi EC, Rheinheimer DS, Gattiboni LC, Kaminski J, Tessier D (2005) Alterações na mineralogia de um Argissolo do Rio Grande do Sul afetado pela fertilização potássica. Rev Bras Ci Solo 29:327-335

Bortoluzzi EC, Tessier D, Rheinheimer DS, Julien JL (2006) The cation exchange capacity of a sandy soil in southern Brazil: an estimation of permanent charge and $\mathrm{pH}$-dependent charges. Eur J Soil Sci 57:356-364

Bortoluzzi EC, Velde B, Pernes M, Dur JC, Tessier D (2008) Vermiculite with hydroxy-aluminium interlayer and kaolinite formation in a subtropical sandy soil from south Brazil. Clay Miner 43:155163

Brindley GW, Brown G (1980) Crystal structures of clays minerals and their X-ray identification. Mineralogical Society, London, Monograph, 5

Britzke D, da Silva LS, Moterle DF, Rheinheimer DS, Bortoluzzi EC (2012) A study of potassium dynamics and mineralogy in soils from subtropical Brazilian lowlands. J Soil Sediment 12:185-197

Brunetto G, Kaminski J, Melo GW (2006) Recuperação e distribuição do nitrogênio fornecido a videiras jovens. Pesq Agr Bras 41:1299-1304

Empresa Brasileira de Pesquisa Agropecuária_EMBRAPA (1997) Manual de métodos de análise de solo. 2rs. Centro Nacional de Pesquisa de Solos. Rio de Janeiro

Deer WA, Howie RA, Zussman J (1965) Rock forming minerals: framework silicates. Longmans Green and Co Ltd, London

Empresa Brasileira de Pesquisa Agropecuária-EMBRAPA (2006) Sistema Brasileiro de classificação de solo. Centro Nacional de pesquisa de solos, Rio de Janeiro

Fanning DS, Keramidas VZ, El-Desoky MA (1989) Micas. In: Dixon JB, Weed SB (eds) Minerals in soil environments, 2nd edn. Soil Sci Soc Am, Madison, pp 552-634, SSSA series, no 1

FAO (2006) World reference base for soil resources WRB. 2nd ed. Roma (World Soil Resources Reports, 103)

Hinsinger P, Jaillard B (1993) Root-induced release of interlayer potassium and vermiculitization of phlogopite as related to potassium depletion in the rhizosphere of ryegrass. J Soil Sci 44:525534

Hinsinger P, Jaillard B, Dufey JE (1992) Rapid weathering of a trioctahedral mica by the roots of ryegrass. Soil Sci Soc Am J 56:977-982
Hughes RE, Moore DM, Glass HD (1994) Qualitative and quantitative analysis of clay minerals in soils. In: Baterls JM (ed) Quantitative methods in soil mineralogy. Soil Sci Soc Am, Madison, pp 330 359

Inda AV, Torrent J, Barron V, Bayer C (2010) Aluminum hydroxyinterlayered minerals and chemical properties of a subtropical Brazilian Oxisol under no-tillage and conventional tillage. Rev Bras Ci Solo 34:33-41

Inoue A (1983) Potassium fixation by clay minerals during hydrothermal treatment. Clays Clay Miner 31:81-91

Inoue A, Bouchet A, Velde B, Meunier A (1989) Convenient technique for estimating smectite layer percentage in randomly interstratified illite/smectite minerals. Clays Clay Miner 37:227-234

Kampf N, Costa Junior MI, Azevedo AC (1995) Estrutura básica de argilomineral 2:1 com hidróxi-Al entrecamadas em Latossolo Bruno do Rio Grande do Sul. Rev Bras Ci Solo 19:185-190

Lanson B (1997) Decomposition of experimental X-ray diffraction patterns (profile fitting): a convenient way to study clay minerals. Clays Clay Miner 45:132-146

Mehra JP, Jackson ML (1960) Iron oxides removal from soils and clays by a dithionite-citrate-bicarbonate system buffered with sodium bicarbonate. Clays Clay Miner 7:317-327

Minasny B, Mcbratney AB, Salvador-Blanes S (2008) Quantitative models for pedogenesis. Geoderma 144:140-157

Moore DM, Reynolds RC (1997) X-ray diffraction and the identification and analysis of clay minerals, 2nd edn. Oxford University Press, New York

Pal DK, Srivastava P, Durge SL, Bhattacharyya T (2001) Role of weathering of fine-grained micas in potassium management of Indian soils. Appl Clay Sci 20:39-52

Pédro G (1979) Les conditions de formation des constituants secondaires. In: Bonneau M, Souchier B (eds) Pédologie: Constituants et propriétés du sol. Masson, Paris, pp 58-71

Pellegrini JBR, Santos DR, Gonçalves CS, Copetti ACC, Bortoluzzi EC, Tessier D (2010) Impacts of anthropic pressures on soil phosphorus availability, concentration, and phosphorus forms in sediments in a Southern Brazilian watershed. J Soil Sediment 10:451-460

Pernes-Debuyser A, Pernes M, Velde B, Tessier D (2003) Soil mineralogy evolution in the INRA 42 Plots experiment (Versailles, France). Clays Clay Miner 51:578-585

Phillips JD (2007) Development of texture contrast soils by combination of bioturbation and translocation. Catena 70:92-104

Pratt PF (1965) Potassium. In: Black CA (ed) Methods of soil analysis, vol 2. ASA, Madison, pp 1022-1030

Schultz LG, Shepard AO, Blackmon PD, Starkey HC (1971) Mixedlayer kaolinite-montmorillonite from the Yucatan península, Mexico. Clays Clay Miner 19:137-150

Schwertmann U, Taylor RM (1989) Iron oxides. In: Dixon JB, Weed SB (eds) Minerals in soil environments, 2nd edn. Soil Sci Soc Am, Madison, pp 379-438, SSSA series, no. 1

Schwertmann U, Schulze DG, Murad E (1982) Identification of ferrihydrite in soils by dissolution kinetics, differential X-ray diffraction and Mossbauer spectroscopy. Soil Sci Soc Am J 46:869-875

Soil Survey Staff (1995) Soil survey manual, USDA handbook no. 45. US Government Printing Office, Washington, DC

Tedesco MJ, Gianello C, Bissani CA, Bohnen H, Volkweiss SJ (1995) Análise de solo, plantas e outros materiais. 2nd edn. University Federal of Rio Grande do Sul, Porto Alegre. Technical Report, 5

Velde B (2001) Clay minerals in the agricultural surface soils in the central United States. Clay Miner 36:277-294

Velde B, Peck T (2002) Clay minerals changes in the Morrow experimental plots, University of Illinois. Clays Clay Miner 50:364 370

Wilson MJ (1999) The origins and formation of clay minerals in soils: past, present and future perspectives. Clay Miner 34:7-25 